\title{
METEOROLOGICAL VARIABLES AND SENSORIAL QUALITY OF COFFEE IN THE MANTIQUEIRA REGION OF MINAS GERAIS
}

\author{
Flávio Meira Borém¹, Marcos Paulo Santos Luz², Thelma Sáfadi³, Margarete Marin Lordelo Volpato \\ Helena Maria Ramos Alves ${ }^{5}$, Rosângela Alves Tristão Borém ${ }^{6}$, Daniel Andrade Maciel $^{7}$
}

(Received: September 28, 2018; accepted: November 27, 2018)

\begin{abstract}
The objective in this study was to identify meteorological variables related to the sensorial quality of the coffees from Mantiqueira region in Minas Gerais. Meteorological conditions are strongly related to the coffee's sensorial characteristics, however, there aren't many studies quantifying this relation. Air temperature and rainfall data were collected and spatialized for regional analysis. These were associated to the 2007 through 2011 coffees' beverage scores. The region was stratified according to relief characteristics. The bigger frequency of high scores occurred on the region's central-south, where coffee cultivation is performed above $900 \mathrm{~m}$ altitude. For the in loco study, meteorological data and coffee samples were collected in selected pilot areas. Coffee crops were selected in three altitude ranges: below $1000 \mathrm{~m}$, between 1000 and 1200 $\mathrm{m}$, and over $1200 \mathrm{~m}$. Above $1000 \mathrm{~m}$ the meteorological variable that presented the biggest variation was the air temperature. Above $1000 \mathrm{~m}$ the smallest thermal amplitude occurred, which provided superior quality coffees. The study demonstrates the importance of the meteorological variable characterization aiming to identify locations with greater vocation to the specialty coffees production.
\end{abstract}

Index terms: Coffee production, agrometeorology, thermal amplitude, altitude.

\section{VARIÁVEIS METEOROLÓGICAS E QUALIDADE SENSORIAL DO CAFÉ NA REGIÃO DA MANTIQUEIRA DE MINAS GERAIS}

\begin{abstract}
RESUMO: Objetivou-se com este estudo identificar variáveis meteorológicas que estão relacionadas à qualidade sensorial dos cafés da região da Mantiqueira de Minas Gerais. Condições meteorológicas são fortemente associadas às características sensoriais dos cafés, porém estudos que quantificam essa relação ainda são escassos. Para análise regional foram coletados e espacializados dados de temperatura do ar e precipitação pluvial, que foram relacionados com as notas de bebida dos cafés nos anos de 2007 a 2011. A região foi estratificada em função das características do relevo. A maior frequência de melhores notas da bebida ocorreu nos municípios localizados na área centro-sul da região, mais frios e chuvosos, e onde a cafeicultura localiza-se acima de $900 \mathrm{~m}$ de altitude. Para o estudo in loco, foram selecionadas áreas piloto para coleta de dados meteorológicos e de amostras de café. Foram selecionadas lavouras de café localizadas em três faixas de altitude: abaixo de $1000 \mathrm{~m}$, entre 1000 e $1200 \mathrm{~m}$ e superior a $1200 \mathrm{~m}$. Acima de $1000 \mathrm{~m}$ a temperatura do ar foi a variável meteorológica para a qual se verificou maior diferença. Acima de $1000 \mathrm{~m}$ ocorreu menor amplitude térmica do ar, o que proporcionou cafés com qualidade superior. O estudo demonstra a importância da caracterização de variáveis meteorológicas visando a identificação de locais com maior vocação para produção de cafés especiais.
\end{abstract}

Termos para indexação: Cafeicultura, agrometeorologia, amplitude térmica, altitude.

\section{INTRODUCTION}

The coffees produced at Mantiqueira region, located Southern Minas Gerais, have been gaining increasing recognition from the market, for they provide beverage with distinct sensorial characteristics. The crops are located in different environmental conditions and many climatic variables may be related to the coffees' sensorial characteristics.
Among the environmental variables related to the coffee's sensory quality, the altitude has been the most studied (Figueiredo et al., 2013; Barbosa et al., 2014; Silva et al., 2015). However, altitude's effects are considered to be indirect, for its variation results in different climatic conditions for the environment. Climate and soil characteristics are among the factors that most affect the coffee trees development (Guyot et al., 1996; Joët et al., 2010).

\footnotetext{
${ }^{1,2}$ Universidade Federal de Lavras/UFLA - Departamento de Engenharia/DEG - Cx. P. 3037 - 37.200-000 - Lavras - MG flavioborem@deg.ufla.br,marcospauloluz@gmail.com

${ }^{3}$ Universidade Federal de Lavras/UFLA - Departamento de Estatística/DES - Cx. P. 3037 - 37.200-000 - Lavras - MG - safadi@des.ufla.br ${ }^{4}$ Empresa de Pesquisa Agropecuária de Minas Gerais/Unidade Sul Campus UFLA - Cx.P. 176 - 37.200-000 - Lavras - MG margarete@epamig.ufla.br

${ }^{5}$ Empresa Brasileira de Pesquisa Agropecuária/Embrapa Café - Parque Estação Biológica - PqEB s/n - 70770-901 - Brasília - DF helena.alves@embrapa.br

${ }^{6}$ Universidade Federal de Lavras/UFLA - Departamento de Biologia/DBI - Cx. P. 3037 - 37.200-000 - Lavras - MG - tristao@dbi.ufla.br ${ }^{7}$ Instituto Nacional de Pesquisas Espaciais/INPE - Pós-Graduação/Sensoriamento Remoto - 12.227-010 - São José dos Campos - SP daniel.maciel@inpe.br
} 
In Central America, studies demonstrate that the average temperature during seed development has influenced the sensorial profile. Positive quality attributes, such as acidity, fruity character and flavor quality have been correlated to the coffee production in cooler microclimates (Bertrand et al., 2012). Workuad et al. (2018) observed that the sucrose content and acidity increase with altitude.

Studies performed at Mantiqueira region showed that coffee quality depends on the interaction between genotype, processing and altitude (Ribeiro et al., 2016; Ramos et al., 2016).

This study's purpose was to identify meteorological variables related to the sensorial quality of the coffees from Mantiqueira region in Minas Gerais and demonstrate the importance of the meteorological characterization to identify locations with greater vocation for specialty coffees production.

\section{MATERIALS AND METHODS}

Mantiqueira region is located Southern in Minas Gerais state, Brazil (Figure 1) with altitudes varying from $800 \mathrm{~m}$ (minimum) at Santa Rita do Sapucaí, to 2250 m (maximum) at Baependi (Figure 2). According to Alves et al. (2016), the coffee crops are distributed mainly on the region's central area (Santa Rita do Sapucaí, São Gonçalo do Sapucaí, Carmo de Minas, Campanha, Pedralva, Conceição do Rio Verde, Cambuquira and Lambari). Figure 3 shows the crops distribution by altitude. About $40 \%$ of the crops are located between 900 and $1000 \mathrm{~m}$ and $50 \%$ between 1000 and $1400 \mathrm{~m}$.

Data provided by AGRITEMPO (MAPA, 2014) were used to spatialize the meteorological variables. The location of the weather stations is shown in Table 1. Spatial distribution maps of annual precipitation and maximum and minimum temperature were obtained using the Inverse Distance Weighting interpolation, which has presented the best results for the region.

To describe the region's coffee sensory quality, beverage scores from the 2007/2008 through 2010/2011 harvests were handed over by the sectors companies that directly work in the region. Highest scores maps were elaborated for each harvest. Spatial distribution of annual precipitation and maximum and minimum temperature data were associated to the coffee's beverage scores.

Pilot areas were selected at Carmo de Minas for collection of meteorological data and coffee samples. Automatic weather stations were installed in coffee crops located at three altitude ranges (below $1000 \mathrm{~m}$, between 1000 and 1200 $\mathrm{m}$, and over $1200 \mathrm{~m}$ ). Air temperature, relative humidity, solar radiation and precipitation data referring to the 2011/12 and 2012/13 harvests were collected.

The description of the coffee beverage sensory quality was carried out using field collected samples, by altitude range. The harvest was performed manually and selectively, collecting only mature fruits, which were processed according to Borém (2008) recommendations.

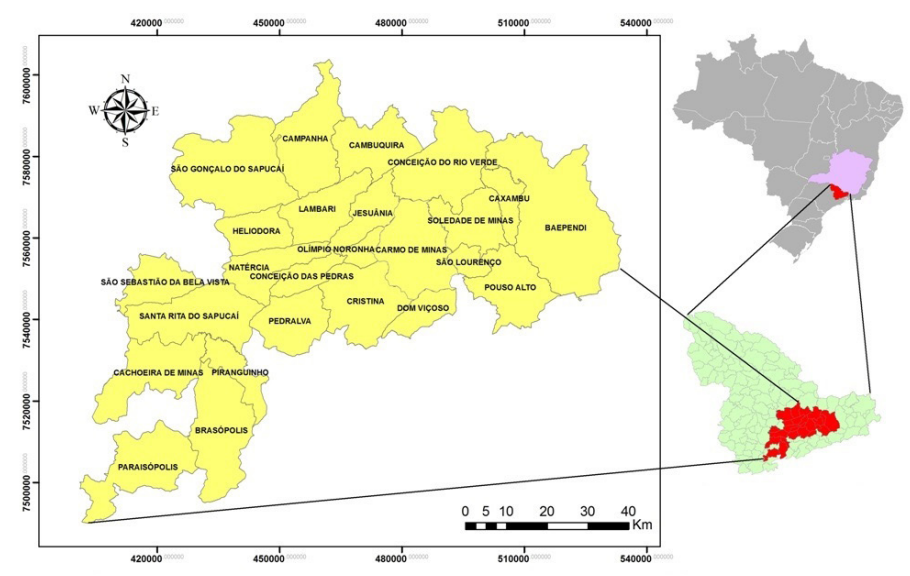

FIGURE 1 - Location of the Mantiqueira region, southern Minas Gerais state, Brazil. 


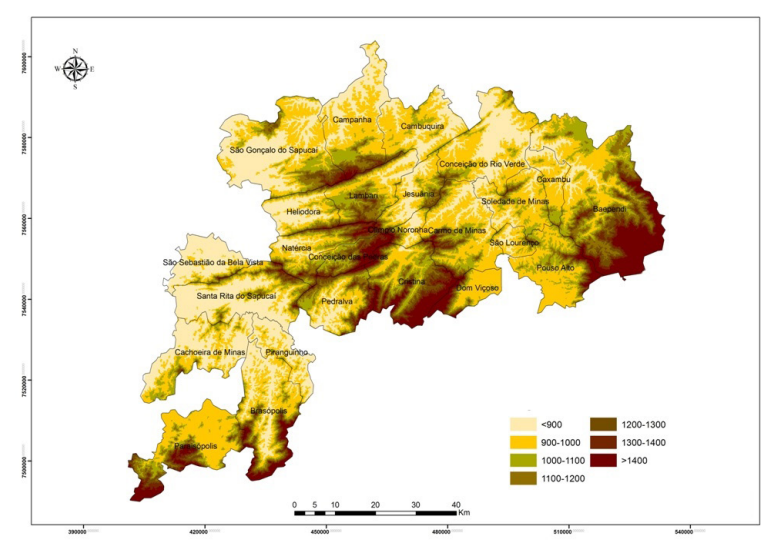

FIGURE 2 - Altitude class map of Mantiqueira region in Minas Gerais, in meters.

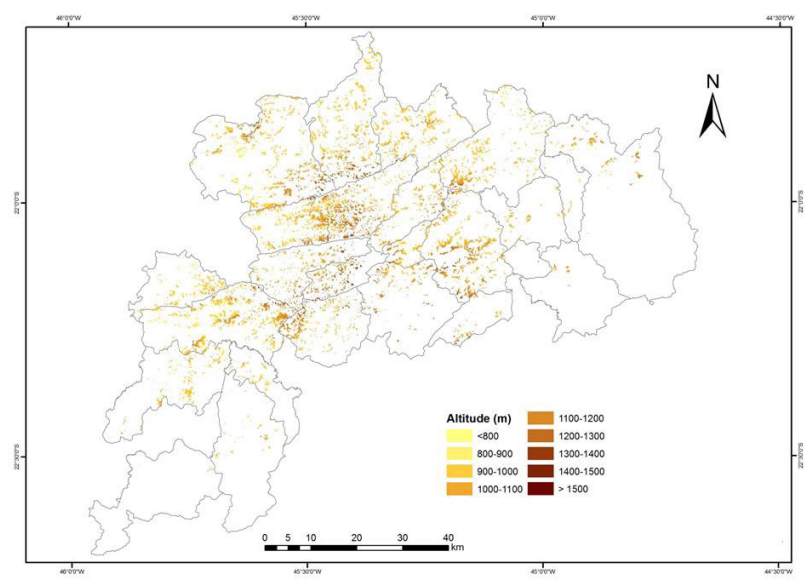

FIGURE 3 - Spatial distribution map of coffee occupied areas, by altitude class, in meters.

TABLE 1 - Locations used to provide air temperature and precipitation data.

\begin{tabular}{lcccc}
\hline \multicolumn{1}{c}{ Location } & Station & Latitude & Longitude & Altitude (m) \\
\hline Aiuruoca/MG & Agritempo & $21^{\circ} 45^{\prime}$ & $44^{\circ} 45^{\prime}$ & 1021 \\
Camanducaia/MG & Agritempo & $22^{\circ} 45^{\prime}$, & $46^{\circ} 00^{\prime}$ & 645 \\
Cambuquira/MG & Agritempo & $21^{\circ} 45^{\prime}$ & $45^{\circ} 15^{\prime}$ & 920 \\
Campos do Jordão/SP & INMET & $22^{\circ} 43^{\prime}$ & $45^{\circ} 34^{\prime}$ & 1580 \\
Lavras/MG & Agritempo & $21^{\circ} 15^{\prime}$ & $45^{\circ} 00^{\prime}$ & 918 \\
Machado/MG & INMET & $21^{\circ} 40^{\prime}$ & $45^{\circ} 55^{\prime}$ & 873 \\
Maria da Fé/MG & $22^{\circ} 18^{\prime}$ & $45^{\circ} 22^{\prime}$ & 1276 \\
São Lourenço/MG & INMET & $22^{\circ} 08^{\prime}$ & $45^{\circ} 02^{\prime}$ & 953 \\
Soledade de Minas/MG & INMET & $22^{\circ} 011^{\prime}$ & $45^{\circ} 05^{\prime}$ & 1148 \\
Varginha/MG & CEMIG & $21^{\circ} 30^{\prime}$ & $45^{\circ} 30^{\prime}$ & 832
\end{tabular}

Agritempo: Agrometeorological Monitoring System; CEMIG: Minas Gerais Energy Company; INMET: National Meteorology Institute. 
The sensorial analysis of the samples was carried out by trained tasters, using the methodology proposed by the Specialty Coffee Association of America (SCAA, 2009). The pilot areas' meteorological data were associated to the sensorial analysis results from the field collected samples.

Time series of meteorological variables (minimum, average and maximum temperature, thermal amplitude, precipitation, solar radiation and relative humidity) were used to perform the statistical analysis of the pilot area data, using the GRETL program. The data was checked for series periodicity. Then, seasonality patterns were graphically evaluated, with autocorrelogram construction. This method allowed the identification of seasonal dependence on the series.

Aiming a comparison, the subtraction between the time series of the meteorological variables on the different altitude ranges (below $1000 \mathrm{~m}$, between 1000 and $1200 \mathrm{~m}$, and over $1200 \mathrm{~m}$ ) was performed. These subtractions were submitted to frequency-domain analysis to check for periodicity in the new series. The stationarity conditions were checked by the autocorrelation function.

\section{RESULTS AND DISCUSSION}

The spatial distribution of meteorological data from Mantiqueira region in Minas Gerais, for the 2007 to 2011 period is presented in Figures 4 through 6.

The region's annual precipitation ranged from 1000 to $2000 \mathrm{~mm}$ and the greatest quantities occurred at the central-south area. The rainier years were 2008, 2009 and 2011. The lower maximum and minimum temperatures occurred at the central-south area. The annual average temperatures ranged from 19 to $22^{\circ} \mathrm{C}, 18$ to $20^{\circ} \mathrm{C}$ and 16 to $18^{\circ} \mathrm{C}$ at north-northeast, central and south areas respectively. According to Vianello and Alves (2012), for every $100 \mathrm{~m}$ of rising altitude, the air temperature drops $0.65^{\circ} \mathrm{C}$. Therefore, the air temperature variation can be explained by latitude difference and by the altitude range of 800 to $2250 \mathrm{~m}$, approximately.

Figures 7 to 10 present the distribution of the highest sensorial scores for the 2007/2008 to $2010 / 2011$ harvests. It's noted values above 80 points for the Carmo de Minas, Dom Viçoso, Cristina, Pedralva, Pouso Alto, Jesuânia, Conceição do Rio Verde, Conceição das Pedras and Olímpio Noronha, at the region's central area. However, excessive rainfall in 2009's harvest period resulted in lower graded coffees.
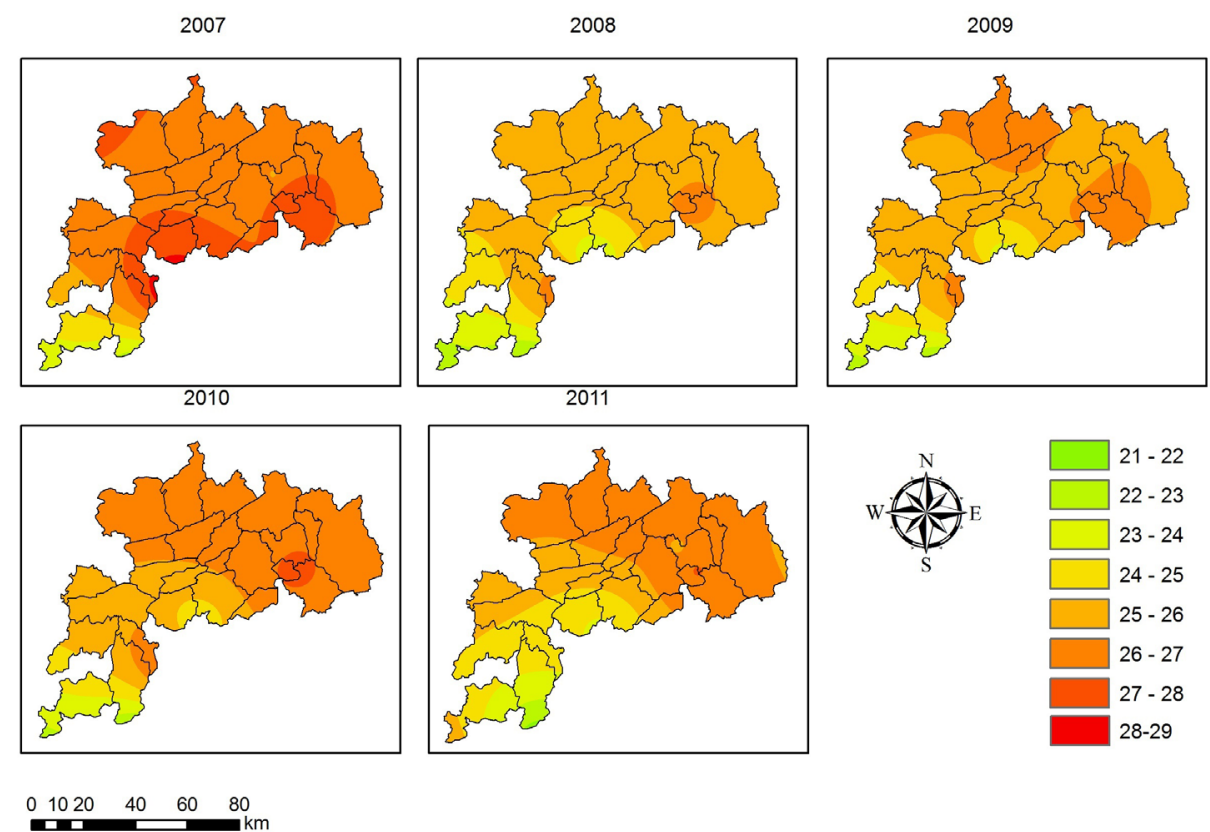

FIGURE 4 - Average maximum temperature maps for the 2007 to 2011 period, in ${ }^{\circ} \mathrm{C}$. 

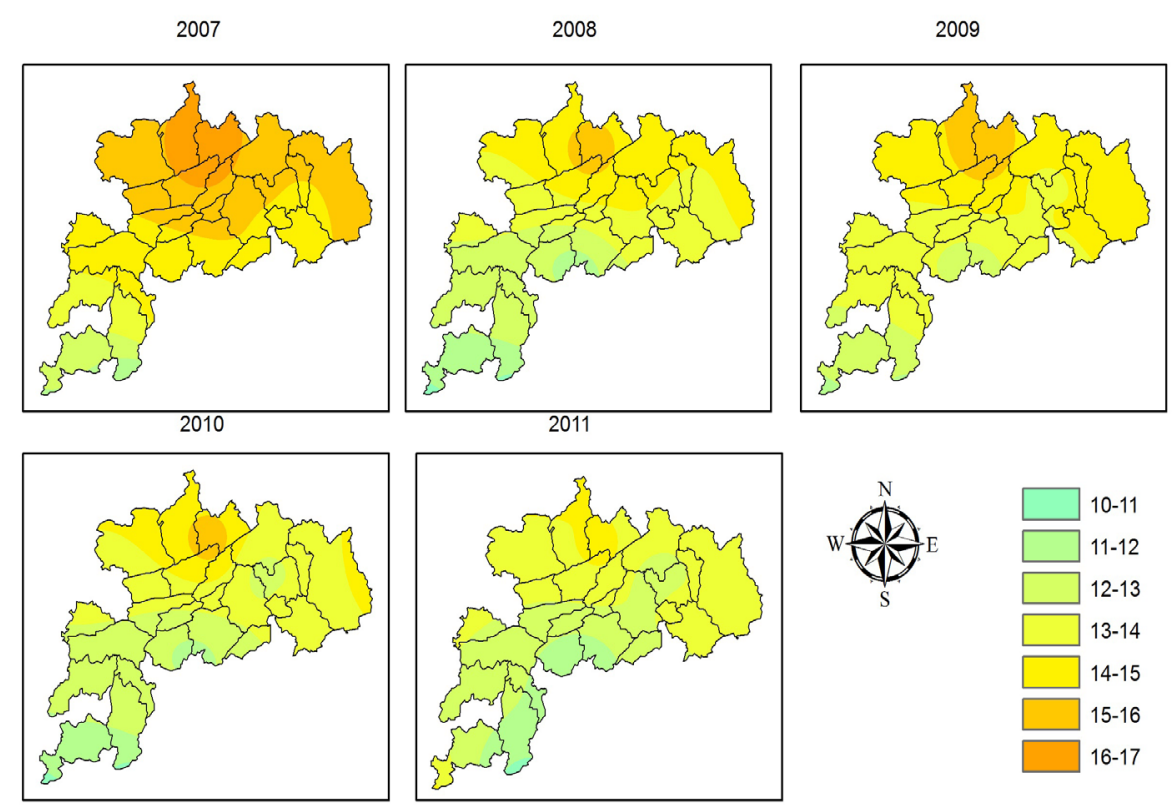

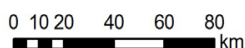

FIGURE 5 - Average minimum temperature maps for the 2007 to 2011 period, in ${ }^{\circ} \mathrm{C}$.
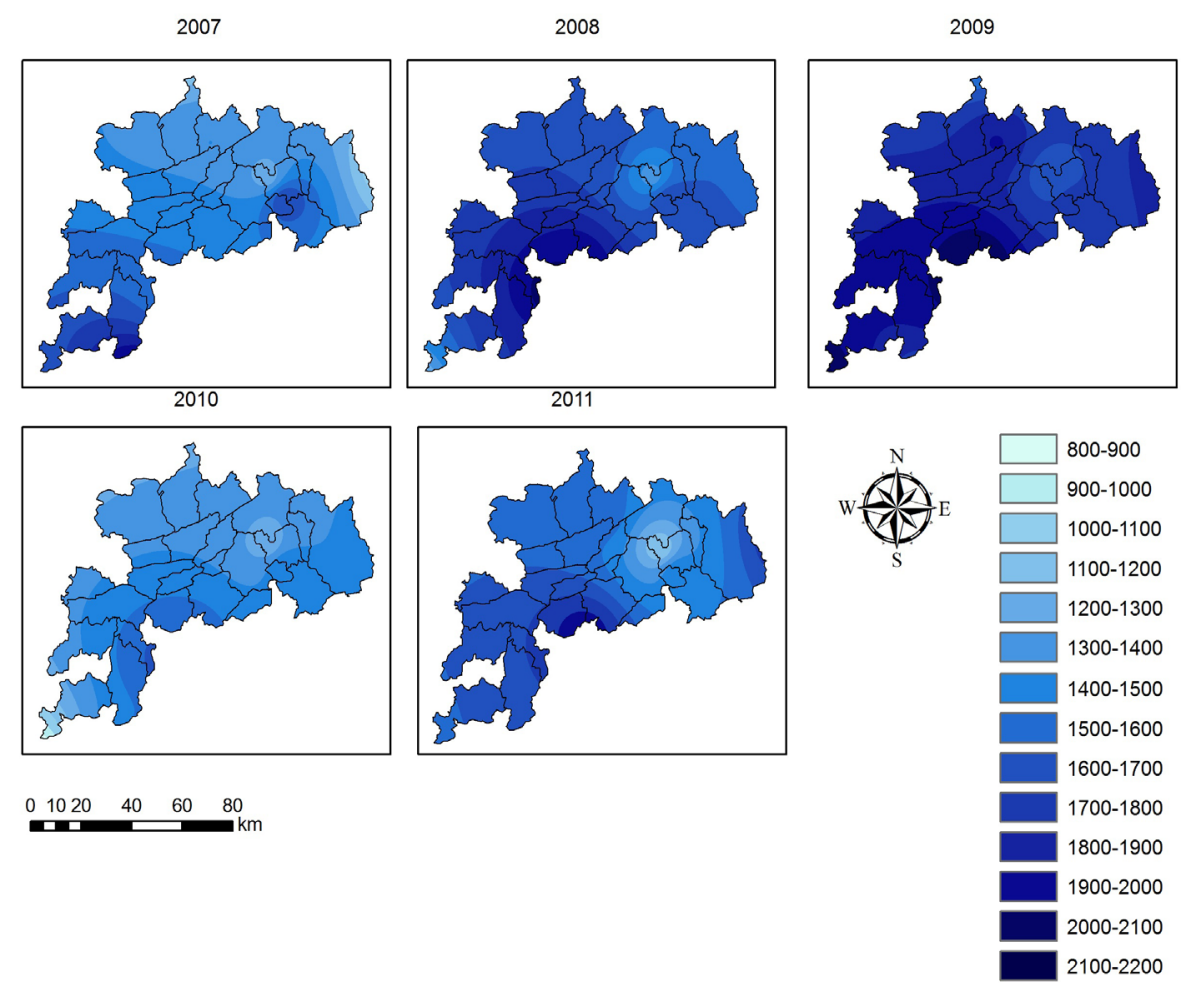

FIGURE 6 - Annual precipitation maps for the 2007 to 2011 period, in mm. 


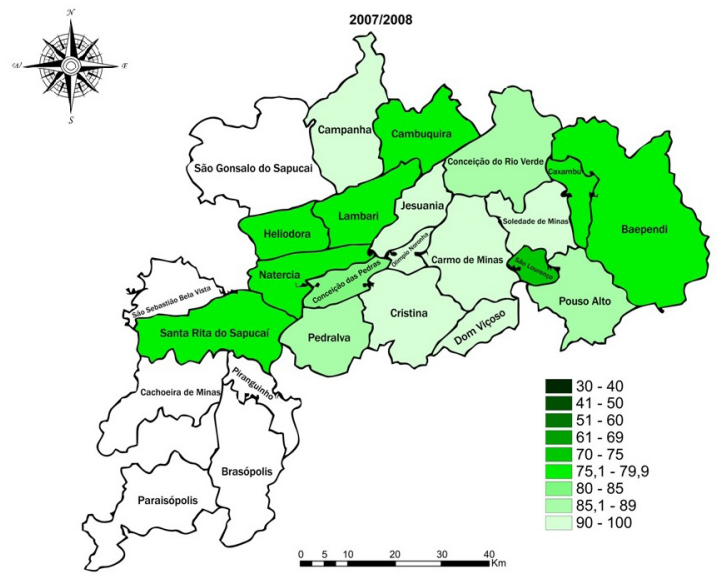

FIGURE 7 - Quality distribution map. Higher scores at 2007/2008 harvest.

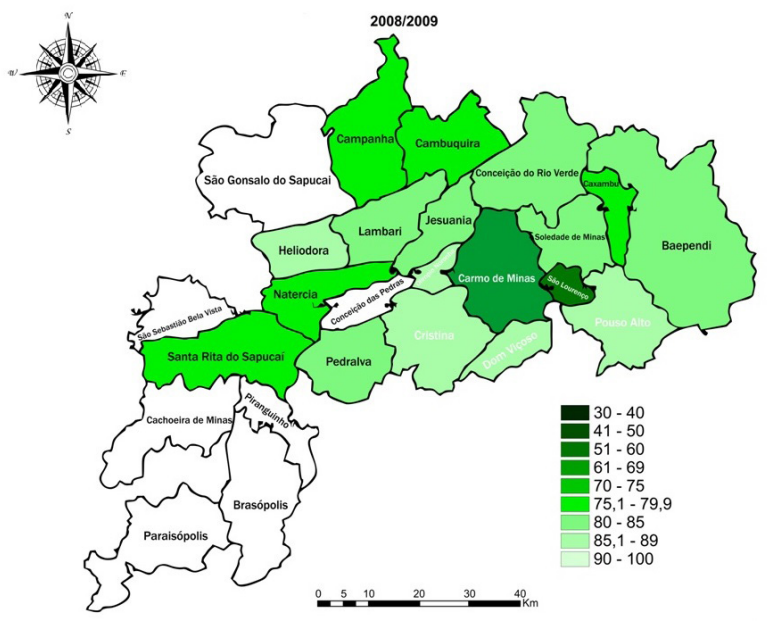

FIGURE 8 - Quality distribution map. Higher scores at 2008/2009 harvest.

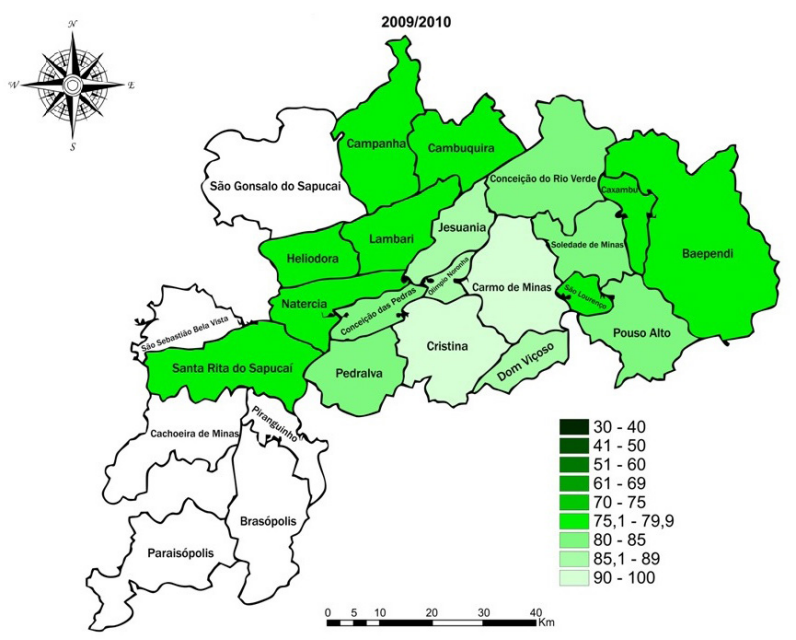

FIGURE 9 - Quality distribution map. Higher scores at 2009/2010 harvest. 


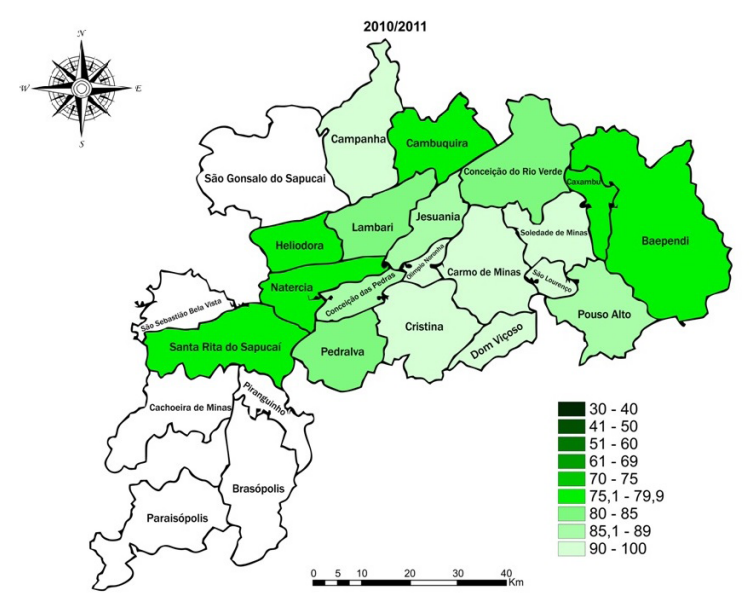

FIGURE 10 - Quality distribution map. Higher scores at 2010/2011 harvest.

In the rest of the region, highest scores values did not exceed 80 points, except for Campanha, which presented scores above 90 points in the 2007/2008 and 2010/2011 harvests.

Scores above 85 points are concentrated at the central-south region, which present the lowest maximum and minimum temperatures. Ribeiro et al. (2016) and Barbosa et al. (2014), while studying the genotype-environment interaction at Carmo de Minas, observed altitude effect on the coffee quality. The Yellow Bourbon genotype, when cultivated above $1200 \mathrm{~m}$, presented a 90 point average grade at sensory quality scores.

These results reveal that the region is stratified according to meteorological characteristics and the coffees at higher and cooler regions present higher scores. Considering the region's great extension, pilot areas were selected to collect meteorological data, according to the altitude.

From the meteorological variables collected at the pilot areas, from july/2011 to june/2013, the air temperature and thermal range were the only ones to present difference between the altitude ranges. The average temperature was $21.6^{\circ} \mathrm{C}$ below $1000 \mathrm{~m}$, and $19.7^{\circ} \mathrm{C}$ above $1000 \mathrm{~m}$. The greater differences occurred in the hotter months (november to march), with values ranging from 2.4 to $2.7^{\circ} \mathrm{C}$ (Figure 11a). The thermal amplitude variation (Figure 11b) was bigger on the altitudes below $1000 \mathrm{~m}$. The greater differences happened in the cooler months (may to september).

The time series subtraction graphs (Figure 12) and correlogram graphs (Figure 13) present the differences, two by two, between the air temperature and thermal amplitude series, at the three altitude ranges. Figure 12 shows growth on the initial part of the series on A, B, C, D and F graphs, which means there's an upward trend.

Figure 12 presents the subtracted series of temperature (minimum, average and maximum) and thermal amplitude for different altitudes. Every situation presented non-zero values, which indicates that there is a difference between the temperature series for distinct altitudes. It is observed in graph (A), for example, that the first observations present an air temperature inversion for the below $1000 \mathrm{~m}$ and between 1000 and $1200 \mathrm{~m}$ environments comparison. The difference between the series remained around $2{ }^{\circ} \mathrm{C}$ until the end of observations. Even though there wasn't temperature inversion in the tested environments from graph $(\mathrm{F})$, the difference between the air temperatures presented a significant increase through the observations, stabilizing around $3^{\circ} \mathrm{C}$. Graph (E) on the other hand presented decreasing values for the subtracted series, which shows a downward trend. These trends are confirmed by the correlograms presented on Figure 13. They show the series' non-stationarity, which is an indicative of the existence of a trend.

The presented results confirm classical literature reports regarding lower average temperatures and coffee's sensorial quality improvement (Avelino et al., 2005; Joët et al., 2010; Bertrand et al., 2012; Workuad et al., 2018). However, a new fact was observed: higher thermal amplitudes are related to the occurrence of inferior quality coffees. 


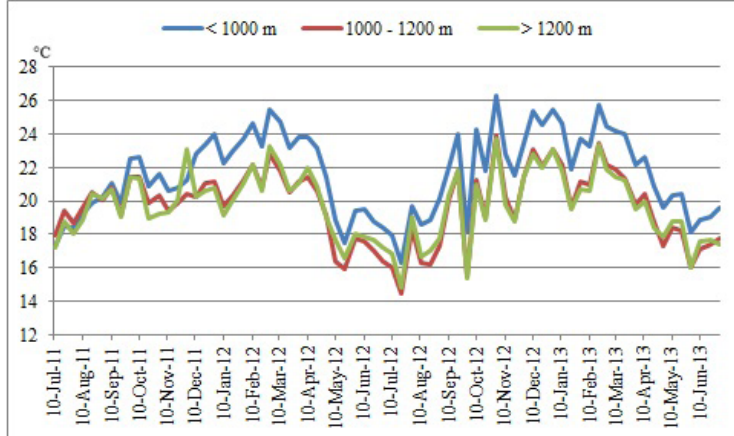

(a)

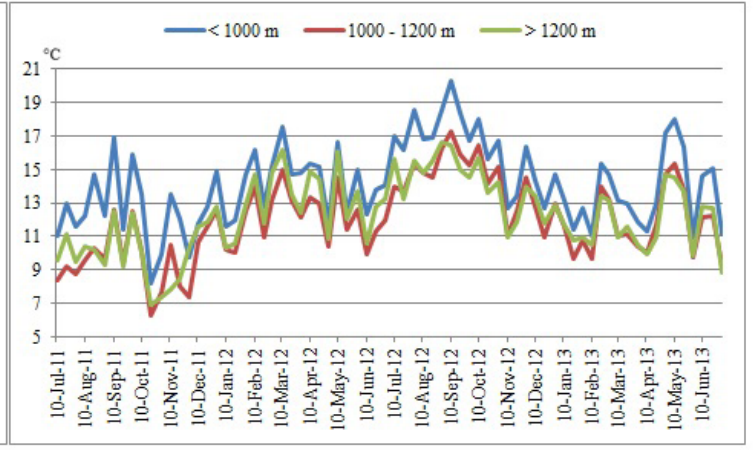

(b)

FIGURE 11 - Average temperature (a) and thermal amplitude (b) from july/2011 to june/2013.
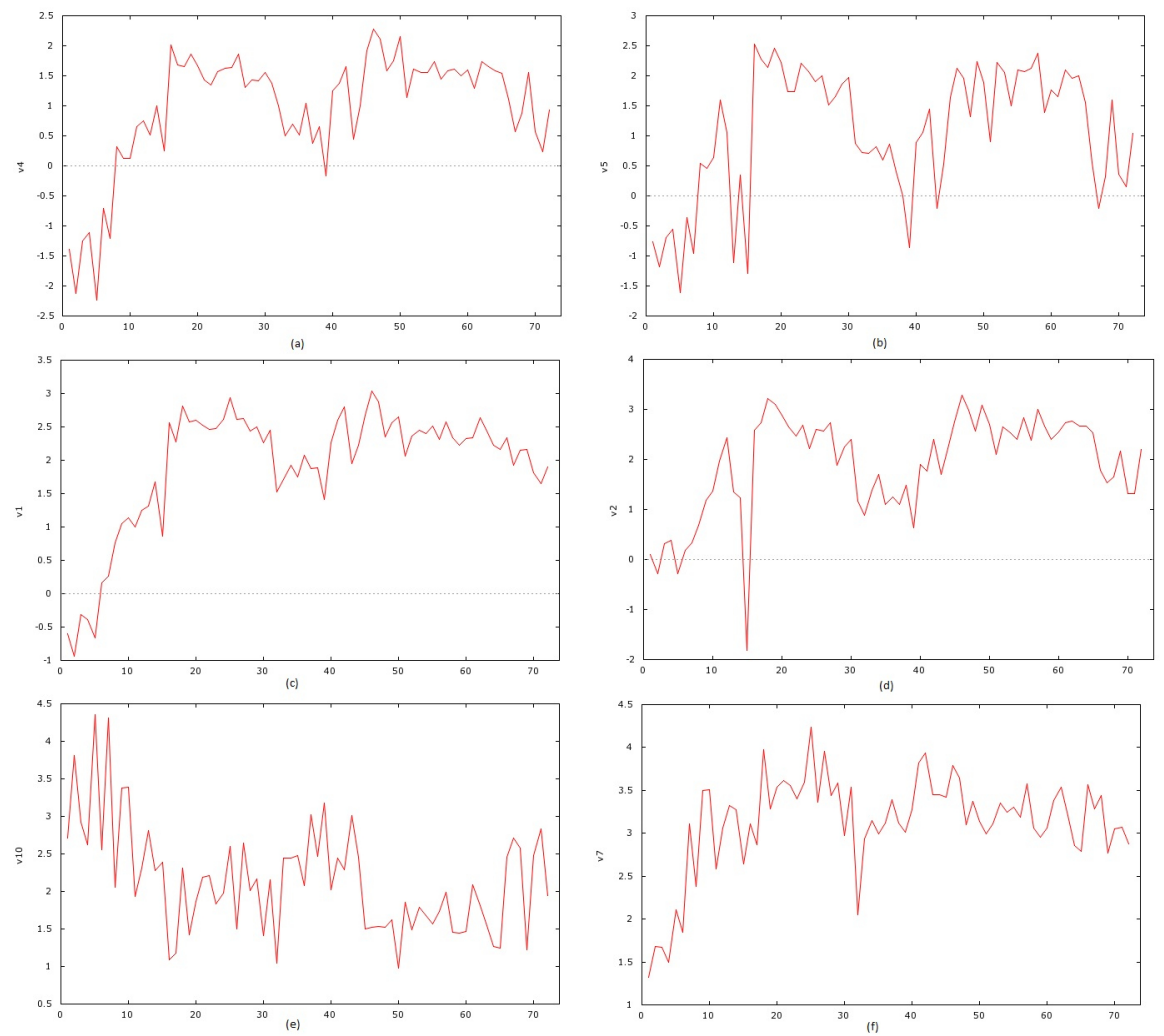

FIGURE 12 - Subtracted series graphs for (A) Minimum Temperature (below $1000 \mathrm{~m}$ - between 1000 and 1200 m), (B) Minimum Temperature (below $1000 \mathrm{~m}$ - above $1200 \mathrm{~m}$ ), (C) Average Temperature (below $1000 \mathrm{~m}$ between 1000 and $1200 \mathrm{~m}$ ), (D) Average Temperature (below $1000 \mathrm{~m}$ - above $1200 \mathrm{~m}$ ), (E) Thermal Amplitude (below $1000 \mathrm{~m}$ - between 1000 and $1200 \mathrm{~m}$ ) e (F) Maximum Temperature (below $1000 \mathrm{~m}$ - between 1000 and $1200 \mathrm{~m})$. 

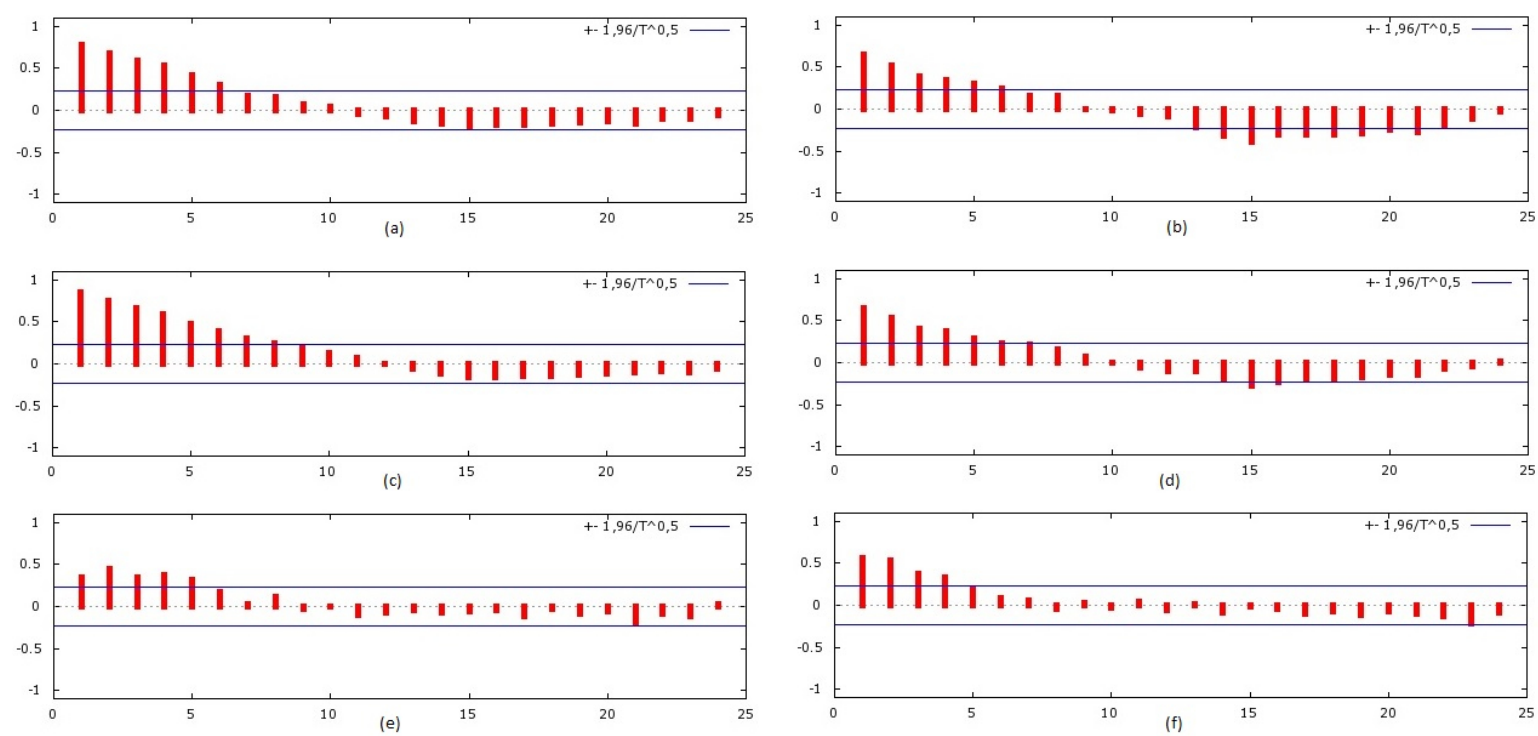

FIGURE 13 - Correlograms for (A) Minimum Temperature (below $1000 \mathrm{~m}$ - between 1000 and $1200 \mathrm{~m}$ ), (B) Minimum Temperature (below $1000 \mathrm{~m}$ - above $1200 \mathrm{~m}$ ), (C) Average Temperature (below $1000 \mathrm{~m}$ - between 1000 and $1200 \mathrm{~m}$ ), (D) Average Temperature (below $1000 \mathrm{~m}$ - above $1200 \mathrm{~m}$ ), (E) Thermal Amplitude (below $1000 \mathrm{~m}$ - between 1000 and $1200 \mathrm{~m}$ ) e (F) Maximum Temperature (below $1000 \mathrm{~m}$ - between 1000 and $1200 \mathrm{~m}$ ).

Many explanations could be related to this fact. Amongst the possibilities, the results obtained by Santos et al. (2018) noted that researches conducted at the same pilot areas, with the objective of studying the ecophyological seasonal variation of arabica coffee of and metabolic attributes, verified that the altitude was determinant for physiological differences. Also, it was noted that plants located in lower altitudes suffered from a bigger oxidative stress, which decreases the beverage quality.)

\section{CONCLUSIONS}

Air temperature was the meteorological variable to present the biggest difference between the altitude ranges above and below the $1000 \mathrm{~m}$. The difference was around $2.5^{\circ} \mathrm{C}$ on the hotter months.

Above $1000 \mathrm{~m}$, the smallest thermal amplitude for the hotter months occurred, which provided superior quality coffees.

The study demonstrates the importance of the meteorological characterization aiming to identify locations with greater vocation to the specialty coffees production.

\section{ACKNOWLEDGMENTS}

The authors acknowledge CNPq, FAPEMIG, CAPES and Consórcio Pesquisa Café.

\section{REFERENCES}

ALVES, H. M. R. et al. Geotechnologies for the characterization of specialty coffee environments of Mantiqueira de Minas in Brazil. The International Archives of the Photogrammetry, Remote Sensing and Spatial Information Sciences, V. 41-B8, p.797799. June 2016. XXIII ISPRS Congress, Commission VIII, Prague, Czech Republic, 2016.

AVELINO, J. et al. Effects of slope exposure, altitude and yield on coffee quality in two altitude terroirs of Costa Rica, Orosi and Santa Maria de Dota. Journal of the Science of Food and Agriculture, London, v. 85, n. 11, p. 1869-1876. May. 2005.

BARBOSA, J. N. et al. Discrimination of production environments of specialty coffees by means of stable isotopes and discriminant model. Journal of Agricultural Science, Ottawa, v. 6, p. 55-64. Apr. 2014.

BERTRAND, B. et al. Climatic factors directly impact the volatile organic compound fingerprint in green Arabica coffee bean as well as coffee beverage quality. Food Chemistry, London, v. 135, p. 2575-2583. July 2012.

BORÉM, F. M. Pós-colheita do café. Lavras: UFLA, 2008. v. 1, p. 631. 
FIGUEIREDO, L. P. et al. The potential for high quality bourbon coffees from different environments. Journal of Agricultural Science, Ottawa, v. 5, n. 10, p. 87-98, Sept. 2013.

GUYOT, B. et al. Influence de l'altitude et de l'ombrage sur la qualité des cafés Arabica. Plantations Recherche Développement, Paris, v.3, n. 4, p. 272-280, July Aug. 1996.

JOËT T. et al. Influence of environmental factors, wet processing and their interactions on the biochemical composition of green Arabica coffee beans. Food Chemistry, v. 118, n. 3, p. 693-701, Feb. 2010.

MAPA - Ministério da Agricultura Pecuária e Abastecimento, Sistema de Monitoramento Agrometeorológico. Available in: <http://www. agritempo.gov.br/agritempo/jsp/Sumario/index. jsp?siglaUF=MG $>$. Access in: Jan. 28. 2014.

RAMOS M. F. et al. Discrimination of the sensory quality of the Coffea arabica L. (cv. Yellow Bourbon) produced in different altitudes using decision trees obtained by the CHAID method. Journal of the Science of Food and Agriculture, London, v. 96, n.10, p 3543-3551, Aug. 2016.
RIBEIRO, D. E. et al. Interaction of genotype, environment and processing in the chemical composition expression and sensorial quality of Arabica coffee. African Journal of Agricultural Research, Nairobi, v. 11, n. 27, p. 2412-2422, July 2016.

SCAA - Specialty Coffee Association of America. 2009. SCAA Protocols - Cupping

Specialty Coffee. Long Beach: SCAA. 2009. 7p.

SANTOS, M. O. et al. Antioxidant system differential regulation is involved in coffee ripening time at different altitudes. Tropical Plant Biology, Switzerland, v. 11, n. 3, p. 131-140, June. 2018.

SILVA, S. de A. et al. Mapping the potential beverage quality of coffee produced in the Zona da Mata, Minas Gerais, Brazil. Journal of the Science of Food and Agriculture, London, v. 96, n. 9, p. 3098-3108, Oct. 2015.

VIANELLO, R.L.; ALVES, A.R. Meteorologia básica e aplicações. 2.ed. Viçosa: Ed. da UFV, 2012. 460p.

WORKUAD, M. et al. Effect of altitude on biochemical composition and quality of green arabica coffee beans can be affected by shade and postharvest processing method. Food Research International, London, v. 105, p. 278-285, Mar. 2018. 